A RCHIWA, BIBLIOTEKI

I MUZEA KOŚCIELNE 111 (2019)

https://doi.org.10.31743/abmk.2019.111.09

\title{
WYKAZ ZNISZCZEŃ W OBIEKTACH SAKRALNYCH DIECEZJI LUBELSKIEJ PO II WOJNIE ŚWIATOWEJ
}

\section{Streszczenie}

Przedstawiony w tekście powojenny obraz zniszczeń kościołów parafialnych diecezji lubelskiej, został oparty na materiale zgromadzonym przede wszystkim w lubelskim Archiwum Archidiecezjalnym. Podstawą do jego tabelarycznego opracowania stały się formularze zawierające informacje o zniszczeniach kościołów, nadsyłane w 1948 roku przez administratorów poszczególnych parafii do kurii biskupiej w Lublinie. Z ich zestawienia wynika, że znaczna liczba Świątyń diecezji lubelskiej została dotknięta skutkami wojny. Największych zniszczeń doznały dekanaty południowo-wschodnie i wschodnie jak dekanat: zamojski, hrubieszowski, tarnogrodzki, tomaszowski, ale także dekanaty zachodnie jak: puławski i opolski. $Z$ uwagi na braki w materiale archiwalnym nie było możliwe ukazanie w tekście pełnej skali zniszczeń, z uwzględnieniem wszystkich kościołów diecezji lubelskiej. Z przedstawionego przeze mnie cząstkowego obrazu strat w świątyniach parafialnych diecezji lubelskiej po II wojnie światowej wynika, że na skutek działań wojennych przeważająca liczba kościołów doznała uszkodzeń zewnętrznych w postaci zniszczonych pokryć i wież, wybitych szyb, uszkodzonych ścian, parkanów; ponadto kilka świątyń zamieniono na magazyny zbożowe, na cerkwie prawosławne lub też zostało spalonych. Ofiarność wiernych, zaangażowanych w odbudowę miejsc kultu, a także powołany przez biskupa ordynariusza lubelskiego - Stefana Wyszyńskiego - Komitet Odbudowy Kościołów Diecezji Lubelskiej odegrały największą rolę w reparacji uszkodzonych i odbudowie zrujnowanych świątyń.

Słowa kluczowe: świątynia; parafia; diecezja; II wojna światowa; odbudowa; straty wojenne

* Joanna Kumor-Mielnik - dr historii; adiunkt w Ośrodku Badań nad Geografią Historyczną Kościoła w Polsce KUL; e-mail: kumorj@poczta.onet.pl

https://orcid.org/0000-0002-4428-9059 
Przedmiotem niniejszego artykułu jest omówienie oraz przedstawienie $\mathrm{w}$ formie tabelarycznego wykazu rozmiaru strat $\mathrm{w}$ budynkach sakralnych diecezji lubelskiej po II wojnie światowej, z pominięciem szczegółowego zagłębiania się w obszerną problematykę działań wojennych i ich skutków na obszarze diecezji lubelskiej. Badane zagadnienie nie doczekało się syntetycznego opracowania. Dostępna od wielu lat praca zbiorowa Życie religijne w Polsce pod okupacja hitlerowska pod redakcją ks. Z.ygmunta Zielińskiego, w której jeden z rozdziałów napisany przez ks. Edwarda Walewandera dotyczy diecezji lubelskiej, koncentruje się raczej na życiu religijnym i na duszpasterstwie niż na stratach materialnych. Wojenne losy miejscowości, parafii i kościołów są przedstawione w poświęconych im licznych monografiach ${ }^{1}$, które mogą w pełni uzupełniać zgromadzony przez nas materiał archiwalny. Materiał ten możemy konfrontować z informacjami zawartymi w tabelarycznym wykazie zniszczeń i strat w zabytkach nieruchomych $\mathrm{w}$ granicach obecnego województwa lubelskiego, poniesionych w wyniku II wojny światowej, opracowanym przez Marzenę Gałecką i zamieszczonym w „Wiadomościach Konserwatorskich Województwa Lubelskiego” (8 (2006) s. 188-207), jak również pomocne przy jego weryfikacji są wiadomości pochodzące z czasopisma „Ochrona Zabytków”2, ale także z poświeconego województwu lubelskiemu siódmego tomu (wyd. w 1973 roku) Zabytków Architektury i Budownictwa w Polsce, opracowanego przez Henryka Gawareckiego, Barbarę Wolff-Łozińską, Jerzego Łozińskiego. Niestety informacje $\mathrm{z}$ powyższych publikacji odnoszą się po pierwsze do historycznego i obecnego terytorium województwa lubelskiego, nie zaś obszaru diecezji lubelskiej, a ponadto dotyczą wyłącznie świątyń objętych ochroną urzędów konserwatorskich.

Podstawę źródłową niniejszego artykułu stanowią przede wszystkim akta zgromadzone w Archiwum Archidiecezjalnym w Lublinie w Dziale IV, poświęconym Wydziałowi Artystyczno-Budowlanemu, jak również akta z Ministerstwa

${ }^{1}$ Wymieniam tylko niektóre z monografii: E. Niedźwiedź, J. Niedźwiedź, J. Siudak, Dzieje miejscowości gminy Miączyn. Powiat zamojski, t. 3, Miączyn-Zamość 2005; W. Zieliński, 600 lat Oszczowa, Oszczów 2009; Polska i Puławy „,na głównym szlaku duchowych dziejów”. Przestrzeń chrześcijańska w kulturze polskiej, red. T. Giergiel, Puławy 2017; R. Wójcik, Kościoły Garbowa, Garbów 1997; Tomaszów Lubelski. Monografia miasta, red. R. Szczygieł, Lublin-Tomaszów Lubelski 2011; R. Tokarczyk, Turobin. Dzieje miejscowości, Lublin 2002; J. Ogiński, Wilków n. Wista. Wieś, parafia, kościót p.w. śś. Floriana i Urszuli. (szkic do monografii), (mps w Wojewódzkiej Bibliotece Publicznej im. H. Łopacińskiego w Lublinie, Dział Bibliografii Lubelszczyzny i Wiedzy o Regionie), 1996 [b.m.w]; J. Markiewicz, Dzieje Biłgoraja. Dzieje najnowsze i współczesne (19181978), cz. 3, w: J. Markiewicz, R. Szczygieł, W. Śladkowski, Dzieje Biłgoraja, Lublin 1985.

${ }^{2}$ Informacje o zniszczeniach i stratach wojennych w zabytkowych kościołach położonych w granicach ówczesnego województwa lubelskiego można odnaleźć w artykułach H. Gawareckiego, Kronika. Prace konserwatorskie. Województwo Lubelskie (1945-1946), „Ochrona Zabytków”, 5 (1952) nr 4 (19) s. 271-277; tenże, Kronika. Prace konserwatorskie. Województwo Lubelskie (1953-1957), „, Ochrona Zabytków”, 11 (1958) nr 1-2 s. 119-129. 
Odbudowy znajdujące się w Archiwum Akt Nowych w Warszawie. Niestety dokumenty nie są kompletne, a zatem na ich postawie nie można w pełni przedstawić badanego zagadnienia. Ich niekompletność wykażemy w dalszej części tekstu.

Informacje o zniszczeniach napływały do kurii biskupiej w Lublinie z poszczególnych parafii, które mocą uchwały Konferencji Plenarnej Episkopatu Polski oraz stosownie do wymagań Ministerstwa Odbudowy w Warszawie zostały zobowiązane pod koniec 1947 roku do składania szczegółowych raportów o stanie świątyń według jednolitego formularza. Zebrane informacje stały się podstawą do opracowania przez kurię, a następnie przedstawienia Ministerstwu Odbudowy w Warszawie Ogólnego zestawienia kosztów na roboty remontowe $i$ odbudowe zburzonych przez dziatania wojenne lub budowę nowych kościołów i zakładów katolickich w diecezji lubelskiej na rok 1948, które miało znaczenie dla kwestii ujednolicenia sposobu finansowania budownictwa kościelnego z funduszy publicznych.

Jak już zaznaczono, zestawienia strat i zniszczeń zgromadzone w materiale archiwalnym z niewiadomych nam przyczyn nie są kompletne, co nie powala na całościowe ukazanie skali problemu, a zarazem na pełne oszacowanie rozmiarów zniszczeń. Zauważono brak formularzy z funkcjonujących w 1948 roku pięciu bardzo ważnych dla omawianej kwestii dekanatów: chełmskiego, kraśnickiego, łęczyńskiego, piaseckiego i szczebrzeszyńskiego ${ }^{3}$. Nie napłynęły również informacje o startach wojennych z kilkunastu parafii należących do kilku innych dekanatów ${ }^{4}$.

W 1948 roku strukturę terytorialną diecezji lubelskiej tworzyło 19 dekanatów ${ }^{5}$, w których funkcjonowały 244 parafie oraz 149 kościołów nieparafialnych wraz z kaplicami (publicznymi, półpublicznymi oraz prywatnymi) ${ }^{6}$. Zgromadzone przez nas informacje o zniszczeniach i stratach wojennych odnoszą się do 142 parafii, a zatem nie posiadamy danych dla 102 parafii. Dodatkowo posiadamy 11

${ }^{3}$ W 1948 roku w skład dekanatu chełmskiego wchodziły 22 parafie, w dekanacie kraśnickim funkcjonowało 17 parafii, w łęczyńskim - 7, w piaseckim 10, w szczebrzeszyńskim -8 .

${ }^{4}$ Brak wykazów szkód wojennych z parafii Łubki i Wojciechów (dekanat bełżycki), z parafii Moniatycze i Werbkowice (dekanat hrubieszowski), z parafii Borów i Godziszów (dekanat janowski lubelski), z parafii Bończa, Krupe, Orłów Murowany, Siennica Różana i Surhów (dekanat krasnostawski), z parafii Kraczewice (dekanat opolski), z parafii Wąwolnica (dekanat puławski), z parafii Dzierążnia, Gródek, Krynice, Majdan Sopocki i Rachanie (dekanat tomaszowski), z parafii Płonka (dekanat turobiński), z parafii Kalinówka, Kosobudy, Łaziska, Wirkowice (dekanat zamojski). Brak również informacji o zniszczeniach świątyń dekanatu lubelskiego: Czerniejów, Jastków, Kazimierzówka, Tomaszowice, Zemborzyce oraz kościołów lubelskich pw. Nawrócenia św. Pawła i p.w. św. Mikołaja na Czwartku, a także lubelskiej katedry pw. św. Jana Chrzciciela i św. Jana Ewangelisty.

${ }^{5}$ Dekanaty te były następujące: bełżycki, biłgorajski, chełmski, hrubieszowski, janowski lubelski, krasnostawski, kraśnicki, lubartowski, lubelski, łęczyński, opolski, piasecki, puławski, szczebrzeszyński, tarnogrodzki, tomaszowski, turobiński, tyszowiecki, zamojski.

${ }^{6}$ Spis kościołów i duchowieństwa diecezji lubelskiej 1948, Lublin 1948. 
raportów dotyczących zniszczeń kościołów filialnych $(4)^{7}$, kaplic $(3)^{8}$ a ponadto kościoła rektoralnego pw. Św. Ducha i św. Anny w Kazimierzu Dolnym, kościoła nieparafialnego pw. św. Rocha w Tarnogrodzie oraz dwóch budynków klasztornych Braci Mniejszych Kapucynów (w Lublinie i Lubartowie).

Formularz, na podstawie którego administratorzy parafii zdawali relacje o stanie budowli sakralnych, składał się z takich wytycznych jak: ogólna charakterystyka kościoła, stan kościoła w roku 1939 i 1944, jego stan obecny (w końcu 1947 roku), liczba wiernych korzystających z kościoła oraz z kilku pytań: czy i gdzie odbywają się nabożeństwa, jakie są zamierzone roboty w 1948 roku, jakie są przewidywane fundusze własne na finansowanie robót, czy pożądane są fundusze publiczne (w tym z kredytów skarbowych i bankowych) oraz jakie kredyty publiczne uzyskano dotychczas?

Zainteresowanie Ministerstwa Odbudowy uszkodzonymi na skutek działań wojennych budynkami sakralnymi i kościelnymi, celem udzielenia tym najbardziej zniszczonym subwencji na odbudowę, było spóźnione, ponieważ większość parafii chcąc kontynuować sprawowanie kultu w świątyniach parafialnych, a tym samym niezwłocznie przywrócić je do stałego użytkowania, sama inicjowała prace remontowo-budowlane, a koszty wszelkiego rodzaju napraw, odbudowy uszkodzonych i zniszczonych obiektów, a nawet wznoszenia ich od podstaw były pokrywane głównie ze składek i dobrowolnych ofiar parafian.

Tylko nieliczne parafie uzyskiwały subwencje lub też korzystały z kredytów na odbudowę. Należały do nich głównie te, których kościoły znajdowały się na liście zabytków architektury i budownictwa województwa lubelskiego. W 1961 roku (nie dysponujemy danymi dla wcześniejszego okresu) na liście zabytków architektury i budownictwa województwa lubelskiego, użytkowanego przez parafie rzymsko-katolickie diecezji lubelskiej, znajdowało się 331 obiektów (w tej liczbie także dzwonnic, kaplic, budynków klasztornych, kościołów nieparafialnych i parafialnych, plebanii, kostnic). Kościołów parafialnych i nieparafialnych było na tej liście ok. $155^{9}$. Jednak tylko kilka parafii otrzymało po II wojnie światowej subwencje na prace budowlane przy zniszczonych wojną obiektach. Z Ministerstwa Kultury i Sztuki w Warszawie oraz z Wydziału Powiatowego w Puławach zapomogę na naprawę zniszczonej zabytkowej dzwonnicy i zabytkowego kościoła parafialnego otrzymała parafia Włostowice ${ }^{10}$. Parafia Puławy na odbudowę historycznej świątyni, na którą podczas nalotu niemieckiego w 1939 roku spadły

${ }^{7}$ Dotyczy następujących kościołów filialnych: Cześniki filia par Horyszów Polski, Honiatycze filia par Dub, Horyszów Ruski filia par Gdeszyn, Miączyn filia par Zawalów.

${ }^{8}$ Łążek Zaklikowski, kaplica parafii Borów, Jadwinów kaplica parafii św. Anny Matki NMP w Lubartowie, Malice kaplica parafii Sahryń.

${ }^{9}$ Archiwum Archidiecezjalne Lubelskie (dalej: AAL), Wydział Artystyczno-Budowlany, Korespondencja dotycząca spraw budownictwa kościelnego 1951-1976, Pismo Wojewódzkiego Konserwatora Zabytków Prezydium Wojewódzkiej Rady Narodowej do Kurii Biskupiej w Lublinie z dn. 28 października 1961 r., sygn. Dz. IV 3025, k. 123-135.

${ }^{10}$ AAL, Wydział Artystyczno-Budowlany, Ogólne zestawienie kosztów na roboty remontowe $i$ odbudowe zburzonych przez działania wojenne lub budowe nowych 1947-, sygn. Dz. IV 3033, k. 131 . 
dwie bomby, otrzymała subwencje z Ministerstwa Kultury i Sztuki, z Ministerstwa Administracji Publicznej oraz z Wydziału Powiatowego w Puławach ${ }^{11}$. Koszty jej odbudowy przewyższały możliwości finansowe parafii, zwłaszcza że nie ocalał nawet uszkodzony dach, z którego żołnierze niemieccy zabrali miedzianą blachę. Zniszczone zostały: strop, portyk, posadzka, neogotycki ołtarz, a po zajęciu Puław przez Armię Czerwoną we wrześniu 1944 roku proboszcz parafii puławskiej wywiózł sprzęty liturgiczne do sąsiednich Włostowic, by uchronić je przed grabieżą, natomiast plebania puławska zajęta została przez sowieckich saperów ${ }^{12}$. Pomocy finansowej udzielił kościołowi rektoralnemu p.w. Św. Ducha i św. Anny w Kazimierzu Dolnym Wojewódzki Wydział Odbudowy oraz Wydział Kultury i Sztuki ${ }^{13}$. Udzielił on także subwencji na naprawę zniszczeń w kościele parafialnym w Kazimierzu Dolnym ${ }^{14}$. Ministerstwo Odbudowy, jak również Ministerstwo Kultury i Sztuki wsparły odbudowę zabytkowego kościoła w Gołębiu oraz zabytkowej plebanii w Kurowie, a także remont dachu na klasztorze Braci Mniejszych Kapucynów w Lubartowie ${ }^{15}$. Materiały budowlane, takie jak cement i szkło, otrzymała z Wydziału Odbudowy parafia Matczyn ${ }^{16}$, parafia Księżpol zaś materiał drzewny na ogrodzenie ${ }^{17}$. Kredyt z Banku Gospodarstwa Krajowego uzyskała parafia Piaski Wielkie ${ }^{18}$. Z kredytów na odbudowę skorzystała parafia Rybitwy ${ }^{19}$, a zapomogę uzyskała parafia Nabró $\dot{z}^{20}$. Parafia Piotrawin otrzymała wsparcie z Urzędu Konserwatorskiego ${ }^{21}$. Kościoły w Piaskach, Rybitwach i Nabrożu zostały spalone podczas działań wojennych i dewastacji przez Niemców, dlatego naprawa szkód wiązała się z wysokimi kosztami przewyższającymi możliwości finansowe samych parafian.

W 44 sprawozdaniach o stanie kościołów po II wojnie światowej administratorzy parafii wykazali, że kościół nie ucierpiał podczas działań wojennych. Dodatkowo 16 parafii bądź nie przedstawiło zniszczeń będących skutkiem wojny, bądź też udzieliło informacji o uszkodzeniach, bez podania ich przyczyn, a powodem dewastacji wielu świątyń był upływ czasu, zaniedbania w remontach

${ }^{11}$ Tamże, k. 129.

${ }^{12}$ Z. Kiełb, Spokojne i niespokojne dzieje puławskiej kaplicy Książat Czartoryskich w latach 180-1948, w: Polska i Pulawy, s. 298-301.

${ }^{13}$ AAL, Ogólne zestawienie kosztów, sygn. Dz. IV 3033, k. 123.

${ }^{14}$ Tamże, k. 122.

15 Tamże, k. 99 (Lubartów), k. 121 (Gołąb), k. 126 (Kurów). Plebania w Kurowie zbudowana w latach 1778-1782 powstała według podania na wzór pewnego domu w Szwajcarii nad jeziorem Lemańskim, który spodobał się ks. Grzegorzowi Piramowiczowi, gdy przebywał tam wraz z właścicielem majątku Kurów, który później wybudował dla swojego proboszcz plebanię. Z inicjatywy ks. G. Piramowicza powstał dom parafialny, w którym mieli się kształcić nauczyciele szkół parafialnych, a także miał on być mieszkaniem dla pracowników parafialnych. W.P. Mazurkiewicz, Kurów lubelski w XX stuleciu, Lublin 2002, s. 91.

${ }^{16}$ AAL, Ogólne zestawienie kosztów, sygn. Dz. IV 3033, k. 130.

${ }^{17}$ Tamże, k. 139.

${ }^{18}$ Tamże, k. 119.

${ }^{19}$ Tamże, k. 115.

${ }^{20}$ Tamże, k. 158.

${ }^{21}$ Tamże, k. 113. 
starych obiektów sakralnych i przestój $\mathrm{w}$ pracach budowlanych przy nowo budowanych świątyniach. Według posiadanych przez nas danych dotyczących 153 parafii diecezji lubelskiej wojna przerwała budowę czterech kościołów parafialnych w: Brzeźnicy Książęcej, Klementowicach, Tuczępach i Zdziłowicach. Podwójną stratę poniosła parafia w Matczynie, gdzie oprócz uszkodzenia starego kościoła, utracono materiał budowlany na wznoszoną od 1937 roku nową świątynię ${ }^{22}$. Cztery kościoły zamieniono na łaźnię lub na magazyn zbożowy (w Grabowcu, Horyszowie Ruskim - filia parafii Gdeszyn, w Zamościu p.w. Zmartwychwstania Pańskiego i św. Tomasza Ap. oraz w Turobinie), natomiast pięć świątyń zostało zamienionych na cerkwie prawosławne (w Biszczy, Luchowie Górnym, Szpikołosach, Zamchu i Żdżannym) ${ }^{23}$. Zamiana kościoła na magazyn zbożowy przez okupanta niemieckiego była przyczyną dewastacji świątyni turobińskiej oraz przejęcia jej funkcji przez małą zakrystię, w której sprawowano Eucharystię ${ }^{24}$.

Skutki zaboru kościołów oraz zabudowań parafialnych katolikom i przekazywania ich prawosławnym, najdotkliwiej dały się odczuć we wschodniej części diecezji lubelskiej ${ }^{25}$.

W wyniku działań wojennych uszkodzonych lub zniszczonych zostało 68 kościołów, w tym lekko uszkodzonych - 5, mocno uszkodzonych -12 , zniszczonych w różnym stopniu -53 , spalonych -9 . W przypadku trzech parafii ucierpiały budynki parafialne, plebania i dom kościelny ${ }^{26}$. Lekkich uszkodzeń doznał na przykład kościół parafialny w Garbowie, w którym w wyniku wstrząsów powstały rysy na suficie i pęknięcia, co groziło jego zawaleniem ${ }^{27}$. Parafie, których kościoły mocno ucierpiały w czasie wojny, przenosiły swoje siedziby do świątyń położonych w sąsiednich miejscowościach. Nabożeństwo z parafii Rybitwy przeniesiono do kościoła parafialnego w Józefowie nad Wisłą,

${ }^{22}$ Tamże, k. 91, 124, 16, 60, 79, 30.

${ }^{23}$ Tamże, passim; Informator diecezji lubelskiej z roku 1985 wymienia ponadto siedem parafii, których kościoły zostały w czasie wojny zamienione na cerkwie prawosławne. Są to parafie: Chełm p.w. Narodzenia NMP, s. 352; Buśno, s. 360; Czartowiec, s. 345-346; Majdan Sopocki, s. 327-328; Nowosiółki, s. 352; Rogóźno, s. 257 i Stężyca, s. 213-214; Diecezja Lubelska. Informator historyczny $i$ administracyjny, oprac. M.T. Zahajkiewicz, Lublin 1985.

${ }^{24}$ Tokarczyk, Turobin, s. 268.

${ }^{25}$ E. Walewander, Diecezja lubelska, w: Życie religijne w Polsce pod okupacja hitlerowska 1939-1945, red. Z. Zieliński, Warszawa 1982, s. 347, 357.

${ }^{26}$ Spalona plebania w parafii Wielącza; spalona wikarówka z mieszkaniem dla organisty i kościelnego wraz z zabudowaniami gospodarczymi, a także zniszczone ogrodzenie cmentarza grzebalnego i ogrodzenie kościoła w parafii Skierbieszów; zniszczona zabytkowa plebania i dom kościelny w Kurowie - dom kościelny murowany z XVIII wieku, niegdyś pierwsza w Polsce szkoła ks. G. Piramowicza, spalony w 1939 r. od bomb niemieckich, a zabytkowa plebania z XVIII wieku spalona w wyniku niemieckiego nalotu w roku 1944: AAL, Wydział Artystyczno-Budowlany, Ogólne zestawienie kosztów, sygn. Dz. IV 3033, k. 170 (Wielącza), k. 167 (Skierbieszów), k. 126 (Kurów). Ponadto Informator diecezji lubelskiej z roku 1985, wymienia 11 parafii, których kościoły doznały uszkodzeń w czasie wojny, a których brak w materiale archiwalnym. Należą do nich parafie: Dorohusk, Józefów nad Wisłą, Kamień, Kijany, Kosobudy, Łaszczów, Mokrelipie, Olbięcin, Świeciechów, Wilkołaz oraz Katedra w Lublinie.

${ }^{27}$ Wójcik, Kościoły Garbowa, s. 64. 
zmieniając nazwę parafii na Józefów-Rybitwy. Siedziba erygowanej w 1921 roku parafii w Borowicy została w 1947 roku przeniesiona do Żulina, przyjmując dwuczłonową nazwę Żulin-Borowica. W 1948 roku na skutek przeniesienia nabożeństwa ze spalonego kościoła parafialnego w Oszczowie do kościoła w Dołhobyczowie powstała parafia Dołhobyczów-Oszczów ${ }^{28}$. Spalenie świątyni parafialnej w Rzeplinie było powodem przeniesienia siedziby parafii do kościoła w Żulicach i zmiany nazwy placówki na Rzeplin-Żulice. Całkowicie zniszczona została świątynia w Sahryniu, z której nabożeństwo do czasu jej odbudowania przeniesiono do Turkowic. Podczas niemieckiego nalotu na Biłgoraj we wrześniu 1939 roku została spalona świątynia, z której nabożeństwo na krótko przeniesiono do pobliskiego kościółka św. Jerzego, ostatecznie jednak i ten w 1941 roku został parafianom zabrany i przemianowany na cerkiew prawosławną. msze święte zaczęto odprawiać w ruinach spalonego kościoła parafialnego, który wysiłkiem wiernych został $\mathrm{w}$ niedługim czasie pokryty dachem ${ }^{29}$. Prace przy odbudowie świątyni biłgorajskiej zrelacjonował w sprawozdaniu proboszcz parafii:

Od 1 października 1939 roku niemało robót dokonano w bardzo trudnych warunkach za rządów niemieckich, a po rozgromieniu Niemców praca poszła w szybszym tempie. Kościół spalony, został odbudowany i pokryty blachą, uszkodzenia zewnętrzne i wewnętrzne usunięte, świątynia otynkowana wewnątrz i zewnątrz. Zrobiono wszystkie nowe drzwi i okna i chór kościelny, a obok tego ułożono posadzkę terrakotową, która skutkiem pożaru w części została zniszczona, a duża ilość takowej zużyta została. Dwie wysokie wieże kościelne nowe przykryte zostały blachą żelazną ocynkowaną, a na szczytach wież dano dwa nowe piorunochrony. Zewnętrzna strona kościoła wykonana całkowicie i prezentuje się nieźle. Wewnętrzna strona świątyni potrzebuje jeszcze wiele pracy i kosztów - długi szereg setek tysięcy złotych. Postawiono dwa ołtarze boczne, ale jeszcze niepomalowane i niepozłocone przyozdobione zostały obrazami: Przemienienie Pańskie, św. Antoni, św. Józef i u góry ołtarzy: obrazy mniejsze św. Anna i bł. Czesław. Wybudowano ambonę ale jeszcze niepomalowana i niepozłocona. Ołtarz wielki jest zrobiony tymczasowo ze starych ołtarzy. Za budowę nowego ołtarza zażądano około 800000 zł. Obok tego mamy zamówić do wymienionego ołtarza dwa obrazy: Św. Trójcę i Wniebowzięcie NMP. Przy nabyciu obrazów pierwszeństwo dajemy świętym, których obrazy mieściły się w kościele biłgorajskim przed spaleniem takowego $0^{30}$.

Według M. Gałeckiej, badającej problematykę zniszczonych po II wojnie światowej zabytków nieruchomych, w tym także kościołów położonych $\mathrm{w}$ granicach obecnego województwa lubelskiego, które ujęte zostały w spisie zabytków z 1931 roku, za najbardziej zniszczone w wyniku działań wojennych uznano kościoły parafialne w Piaskach (zniszczony w 80\%), Biłgoraju (w 40\%),

${ }^{28}$ Zieliński, 600 lat Oszczowa, s. 85-87

${ }^{29}$ Markiewicz, Dzieje Biłgoraja, s. 230-231.

${ }^{30}$ AAL, Wydział Artystyczno-Budowlany, Ogólne zestawienie kosztów, sygn. Dz. IV 3033, k. 34 . 
w Puławach (w 30\%), w Gołębiu (w 30\%), w Józefowie (w 20\%) ${ }^{31}$. Wymienione kościoły funkcjonowały po II wojnie światowej na obszarze diecezji lubelskiej. Poza nimi autorka wyszczególniła jeszcze 29 zabytkowych obiektów sakralnych (rzymskokatolickich kościołów parafialnych, filialnych, rektoralnych oraz kaplic), dotkniętych zniszczeniami wojennymi, a zarazem położonych w ówczesnych granicach diecezji lubelskiej i na obecnym terytorium województwa lubelskiego. Zaliczają się do nich kościoły parafialne w Annopolu, Batorzu, Puszczy Solskiej, Dubience, Kazimierzu Dolnym (kościół parafialny i dwa kościoły rektoralne), Klesztowie, Lipsku, Lublinie (dwa kościoły parafialne i cztery rektoralne), Markuszowie (kościół parafialny i rektoralny), Nabrożu, Oszczowie, Piotrawinie (kościół parafialny z kaplicą), Rachaniach, Rybitwach, Rzeplinie, Świeciechowie, Wilkołazie oraz kaplica w Polanówce (parafia Wilków), Świątynia Sybilli w Puławach i kaplica w Gołębiu ${ }^{32}$.

Najwięcej strat poniosły kościoły położone w południowych i zachodnich dekanatach tj.: puławskim, opolskim, kraśnickim, hrubieszowskim, tyszowieckim, tomaszowskim, zamojskim, znacznie mniej zaś skutkami wojennymi zostały dotknięte dekanaty centralne, tj.: krasnostawski, piasecki, łęczyński. To właśnie Zamojszczyzna doznała ogromnych zniszczeń zarówno w wymiarze materialnym, jak i ludzkim, będących skutkiem agresji i okupacji niemieckiej. Podjęte przez Niemców wyniszczające działania eksterminacyjne, przymusowe wysiedlenia, którym towarzyszyły egzekucje, bombardowania wsi i miast, doprowadziły do wyludnienia terenu Zamojszczyzny, skąd ludność ratowała się ucieczką bądź do lasów, bądź do wsi nieobjętych akcją wysiedleńczą. Dodatkowo południowowschodnią Zamojszczyznę plądrowały oddziały zorganizowane przez Ukraińską Powstańczą Armię, z którymi walczyli żołnierze Armii Krajowej i Batalionów Chłopskich. Działalność nacjonalistów ukraińskich na Zamojszczyźnie doprowadziła do całkowitego zniszczenia kilkudziesięciu wsi i spowodowała śmierć ok. ośmiu tysięcy osób ${ }^{33}$. Z płomieni, które trawiły zabudowania miast i wsi, nie ocalały również świątynie. Potwierdzają to sprawozdania złożone przez nieco więcej niż połowę administratorów parafii diecezji lubelskiej, z których wyłania się realny obraz zniszczeń budowli sakralnych.

Informacje o nim zawierają poniższe zestawienia, sporządzone na podstawie wspomnianych już 153 formularzy nadesłanych do kurii biskupiej w Lublinie przez administratorów parafii. W zestawieniu pominięto 16 parafii, które nie wykazały, czy placówka poniosła straty oraz czy zaistniałe uszkodzenia były spowodowane działaniami wojennymi, czy też nie. Uwzględniono natomiast 44 parafie, które przekazały, że ich świątynie nie ucierpiały w czasie wojny.

${ }^{31}$ M. Gałecka, Zniszczenia i straty $w$ zabytkach nieruchomych $w$ granicach obecnego województwa lubelskiego, poniesione w wyniku II wojny światowej, „Wiadomości Konserwatorskie Województwa Lubelskiego", 8 (2006) s. 191.

${ }^{32}$ Tamże, s. 196-207. W posiadanym przez nas materiale źródłowym nie ma informacji o uszkodzeniach wojennych kościołów w Annopolu i Batorzu, które uwzględniła w swoim wykazie autorka artykułu. W przypadku kościoła parafialnego w Batorzu posiadamy informację, że nie poniósł on strat wojennych.

${ }^{33}$ M. Kulik, Zamojszczyzna pamięta i oskarża, Lublin 2009, s. 9-13. 
Tabela 1. Zniszczenia świątyń i budynków parafialnych diecezji lubelskiej po II wojnie światowej według relacji administratorów parafii

\begin{tabular}{|c|c|c|c|c|}
\hline $\begin{array}{l}\text { Nr karty } \\
\text { jednostki } \\
\text { archiwalnej }\end{array}$ & $\begin{array}{l}\text { Parafia, filia, kaplica, } \\
\text { klasztor }\end{array}$ & $\begin{array}{l}\text { Dekanat } \\
\text { w } 1948 \text { r. }\end{array}$ & $\begin{array}{l}\text { Stan w } 1944 \text { r. wedlug } \\
\text { sprawozdań }\end{array}$ & $\begin{array}{l}\text { Stopień } \\
\text { uszkodzenia/ } \\
\text { zniszczenia }\end{array}$ \\
\hline 1 & 2 & 3 & 4 & 5 \\
\hline K. 108 & Suchowola & Lubartowski & $\begin{array}{l}\text { Nie poniósł większych szkód } \\
\text { z wyjątkiem wybitych części } \\
\text { szyb od wstrząśnienia bomby } \\
\text { dalej upadłej i trochę dachówek } \\
\text { co zostało zaraz naprawione }\end{array}$ & $\begin{array}{l}\text { Lekko } \\
\text { uszkodzony }\end{array}$ \\
\hline K. 15 & $\begin{array}{l}\text { Lublin Klasztor Braci } \\
\text { Mniejszych Kapucynów }\end{array}$ & Lubelski & Lekkie uszkodzenie & $\begin{array}{l}\text { Lekko } \\
\text { uszkodzony }\end{array}$ \\
\hline K. 14 & $\begin{array}{l}\text { Lublin św. Teresy od } \\
\text { Dzieciątka Jezus }\end{array}$ & Lubelski & Nieznaczne uszkodzenia & $\begin{array}{l}\text { Lekko } \\
\text { uszkodzony }\end{array}$ \\
\hline K. 47 & Garbów & Puławski & Mało uszkodzony w 1944 r. & $\begin{array}{l}\text { Lekko } \\
\text { uszkodzony }\end{array}$ \\
\hline K. 132 & Żyrzyn & Puławski & $\begin{array}{l}\text { Większych uszkodzeń nie } \\
\text { poniósł, bliskie wybuchy bomb } \\
\text { uszkodziły jeden witraż i tynki } \\
\text { zewnętrzne }\end{array}$ & $\begin{array}{l}\text { Lekko } \\
\text { uszkodzony }\end{array}$ \\
\hline K. 35 & Frampol & Biłgorajski & $\begin{array}{l}\text { We wrześniu } 1939 \text { r. mocno } \\
\text { uszkodzony przez bomby } \\
\text { zrzucane z samolotów } \\
\text { niemieckich, zburzona połowa } \\
\text { dachu, zwalona wysoka wieża } \\
\text { gotycka, drzwi i wszystkie okna } \\
\text { wraz z ramami powypadały, } \\
\text { tynki na zewnątrz i wewnątrz } \\
\text { świątyni poodpadały od murów }\end{array}$ & $\begin{array}{l}\text { Mocno } \\
\text { uszkodzony }\end{array}$ \\
\hline K. 40 & Majdan Stary & Biłgorajski & $\begin{array}{l}\text { Kościół mocno zniszczono } \\
\text { na zewnątrz i wewnątrz, } \\
\text { potłuczono ołtarze, podarto } \\
\text { chorągwie, rozbito organy, } \\
\text { podarto i wykradziono kościelną } \\
\text { bieliznę; zniszczono baldachim } \\
\text { i wszystkie kapy, rozbito } \\
\text { ambonę }\end{array}$ & $\begin{array}{l}\text { Mocno } \\
\text { uszkodzony }\end{array}$ \\
\hline K. $51-52$ & Dubienka & Hrubieszowski & $\begin{array}{l}\text { Dwukrotnie zrujnowany w } 1941 \\
\text { i } 1944 \text { r., ruina była wielka } \\
\text { (drzwi, okna, wieże, wnętrze } \\
\text { kościoła) }\end{array}$ & $\begin{array}{l}\text { Mocno } \\
\text { uszkodzony }\end{array}$ \\
\hline K. 76 & Polichna & Janowski lubelski & Znacznie zniszczony & $\begin{array}{l}\text { Mocno } \\
\text { uszkodzony }\end{array}$ \\
\hline K. 82 & Krasnystaw & Krasnostawski & $\begin{array}{l}\text { Uszkodzony przez działania } \\
\text { wojenne wewnątrz i na zewnątrz }\end{array}$ & $\begin{array}{l}\text { Mocno } \\
\text { uszkodzony }\end{array}$ \\
\hline K. 115 & Rybitwy & Opolski & Uszkodzony w $60 \%$ & $\begin{array}{l}\text { mocno } \\
\text { uszkodzony }\end{array}$ \\
\hline K. 116 & Wilków & Opolski & $\begin{array}{l}\text { Stan kościoła i budynków } \\
\text { parafialnych rozpaczliwy, } \\
\text { poważnie uszkodzone, w kościół } \\
\text { wpadła bomba i wybiła ogromną } \\
\text { dziurę, tynk zupełnie odpadł na } \\
\text { całym kościele, okna z ramami } \\
\text { wypadły, dach zupełnie } \\
\text { zniszczony, wewnątrz kościół ze } \\
\text { wszystkiego został odarty }\end{array}$ & $\begin{array}{l}\text { Mocno } \\
\text { uszkodzony }\end{array}$ \\
\hline
\end{tabular}




\begin{tabular}{|c|c|c|c|c|}
\hline 1 & 2 & 3 & 4 & 5 \\
\hline K. 121 & Gołąb & Puławski & $\begin{array}{l}\text { Dachy nad kościołem i zakrystią } \\
\text { spalone całkowicie, obydwie } \\
\text { wieże rozbite, (mury i hełmy } \\
\text { wieżowe, piękny szczyt między } \\
\text { wieżami zwalony całkowicie, } \\
\text { cały kościół z zewnątrz } \\
\text { pokaleczony od pocisków) }\end{array}$ & $\begin{array}{l}\text { Mocno } \\
\text { uszkodzony }\end{array}$ \\
\hline K. 122 & Kazimierz Dolny & Puławski & $\begin{array}{l}\text { Sporo ucierpiał: dachy } \\
\text { mocno potłuczone, kaplica } \\
\text { z południowej strony została } \\
\text { rozbita w } 60 \% \text {, okna wszystkie } \\
\text { rozbite, plebania i organistówka } \\
\text { rozbite w } 60 \% \text {, budynki } \\
\text { zniszczone, a niektóre znikły } \\
\text { zupełnie }\end{array}$ & $\begin{array}{l}\text { Mocno } \\
\text { uszkodzony }\end{array}$ \\
\hline K. 123 & $\begin{array}{l}\text { Kazimierz Dolny, kościół } \\
\text { rektoralny Św. Ducha i św. } \\
\text { Anny Matki NMP }\end{array}$ & Puławski & $\begin{array}{l}\text { Kościół zniszczony zewnątrz } \\
\text { i wewnątrz }\end{array}$ & $\begin{array}{l}\text { Mocno } \\
\text { uszkodzony }\end{array}$ \\
\hline K. 129 & Puławy & Puławski & $\begin{array}{l}\text { Po zakończeniu działań } \\
\text { wojennych zniszczony w } 60 \%\end{array}$ & $\begin{array}{l}\text { Mocno } \\
\text { uszkodzony }\end{array}$ \\
\hline K. 131 & Włostowice & Puławski & $\begin{array}{l}\text { Stan opłakany, mocno } \\
\text { uszkodzony }\end{array}$ & $\begin{array}{l}\text { Mocno } \\
\text { uszkodzony }\end{array}$ \\
\hline K. 170 & Wielącza & Zamojski & Spalona plebania & Spalona plebania \\
\hline K. 34 & Biłgoraj & Biłgorajski & $\begin{array}{l}29 \text { września } 1939 \text { r. kościół } \\
\text { całkowicie spalony przez } \\
\text { Niemców, pozostały tylko nagie } \\
\text { mury. Obok tego spalone zostały } \\
\text { następujące obiekty: probostwo, } \\
\text { wikariat z organistówką, } \\
\text { wszystkie budynki } \\
\text { ekonomiczne. Ofiarą ognia stał } \\
\text { się dom katolicki, społeczny, } \\
\text { wraz z budynkami - pozostały } \\
\text { tylko z domu społecznego mury } \\
\text { ceglano-kamienne }\end{array}$ & Spalony \\
\hline K. 119 & Piaski Wielkie & Piasecki & $\begin{array}{l}\text { Zburzony i spalony przez } \\
\text { Niemców }\end{array}$ & Spalony \\
\hline K. 156 & Honiatycze filia par Dub & Tyszowiecki & Spalony & Spalony \\
\hline K. 159 & Malice kaplica par Sahryń & Tyszowiecki & Spalony & Spalony \\
\hline K. 158 & Nabróż & Tyszowiecki & Spalony, pozostały mury & Spalony \\
\hline K. 156 & $\begin{array}{l}\text { Oszczów, par Oszczów- } \\
\text { Dołhobyczów }\end{array}$ & Tyszowiecki & $\begin{array}{l}\text { Spalony w } 1944 \text { przez } \\
\text { Ukraińców }\end{array}$ & Spalony \\
\hline K. 156 & Rzeplin, par Rzeplin-Żulice & Tyszowiecki & Spalony & Spalony \\
\hline K. 160 & $\begin{array}{l}\text { Sahryń, par Turkowice- } \\
\text { Sahryń }\end{array}$ & Tyszowiecki & $\begin{array}{l}\text { W Sahryniu spalony } 10 \text { III 1944, } \\
\text { nabożeństwa odbywają się } \\
\text { w Turkowicach }\end{array}$ & Spalony \\
\hline
\end{tabular}




\begin{tabular}{|c|c|c|c|c|}
\hline 1 & 2 & 3 & 4 & 5 \\
\hline K. 163 & Lipsko & Zamojski & $\begin{array}{l}\text { Spalony i częściowo mury } \\
\text { zniszczone, trudne do } \\
\text { odbudowania, nabożeństwa } \\
\text { odbywają się w baraku }\end{array}$ & Spalony \\
\hline K. 126 & Kurów & Puławski & $\begin{array}{l}\text { Zniszczone dom kościelny } \\
\text { i zabytkowa plebania }\end{array}$ & $\begin{array}{l}\text { Uszkodzone } \\
\text { plebania i dom } \\
\text { kościelny }\end{array}$ \\
\hline K. 127 & Markuszów & Puławski & $\begin{array}{l}\text { Kościół parafialny bez szyb } \\
\text { i bez jednego okna, kościół } \\
\text { Św. Ducha był bez okien } \\
\text { i zrujnowany dach na kościele }\end{array}$ & $\begin{array}{l}\text { Uszkodzone dwa } \\
\text { kościoły }\end{array}$ \\
\hline K. 167 & Skierbieszów & Zamojski & $\begin{array}{l}\text { Całkowicie spalona } \\
\text { wikarówka z mieszkaniem } \\
\text { dla organisty i kościelnego } \\
\text { wraz z zabudowaniami } \\
\text { gospodarczymi, zniszczone } \\
\text { ogrodzenie cmentarza } \\
\text { grzebalnego i ogrodzenie } \\
\text { kościoła }\end{array}$ & $\begin{array}{l}\text { Uszkodzone } \\
\text { budynki } \\
\text { parafialne }\end{array}$ \\
\hline K. 24 & Bychawa & Bełżycki & $\begin{array}{l}\text { Ramy okienne i szkło w oknach } \\
\text { zniszczone z powodu eksplozji }\end{array}$ & Uszkodzony \\
\hline K. 38 & Krzeszów & Biłgorajski & $\begin{array}{l}\text { Ołtarze boczne i dach mocno } \\
\text { uszkodzone, uszkodzone witraże } \\
\text { w oknach. Kościół stoi na górce. } \\
\text { Po wodę trzeba chodzić z góry } \\
\text { do źródła oddalonego jakieś } 170 \\
\text { metrów. W roku } 1944 \text { tylko przy } \\
\text { olbrzymim wysiłku parafian } \\
\text { ugaszono pożar kościoła, } \\
\text { który zapalił się od pocisku } \\
\text { karabinowego }\end{array}$ & Uszkodzony \\
\hline K. 42 & Puszcza Solska & Biłgorajski & $\begin{array}{l}\text { Uszkodzony w } 1939 \text { r. podczas } \\
\text { działań wojennych }\end{array}$ & Uszkodzony \\
\hline K. 50 & Buśno & Hrubieszowski & Ruina i zniszczenia & Uszkodzony \\
\hline K. 49 & Hrubieszów & Hrubieszowski & $\begin{array}{l}\text { Dach podziurawiony i szyby } \\
\text { wybite z powodu działań } \\
\text { wojennych }\end{array}$ & Uszkodzony \\
\hline K. 56 & Kryłów & Hrubieszowski & $\begin{array}{l}\text { Uszkodzona wieża i zerwany } \\
\text { dach na wieży, uszkodzony dach } \\
\text { na kościele, zburzona murowana } \\
\text { organistówka }\end{array}$ & Uszkodzony \\
\hline K. 65 & Miączyn filia par Zawalów & Hrubieszowski & $\begin{array}{l}\text { Kościół zniszczony, odrapany, } \\
\text { pełen zacieków o zupełnie } \\
\text { zrujnowanym dachu }\end{array}$ & Uszkodzony \\
\hline K. 57 & Strzyżów & Hrubieszowski & Uszkodzony & Uszkodzony \\
\hline K. 59 & Trzeszczany & Hrubieszowski & $\begin{array}{l}\text { Częśsiowo powypadały szyby } \\
\text { i był dziurawy dach }\end{array}$ & Uszkodzony \\
\hline
\end{tabular}




\begin{tabular}{|c|c|c|c|c|}
\hline $\mathbf{1}$ & 2 & 3 & 4 & 5 \\
\hline K. 61 & Uchanie & Hrubieszowski & $\begin{array}{l}\text { Ściany zarysowane, latarnie } \\
\text { na dwu kopułach frontowych } \\
\text { pochylone, grożą zawaleniem, } \\
\text { kopuła nad kaplicą ma strącony } \\
\text { krzyż z latarnią, zacieka } \\
\text { i grozi odpadnięciem cennej } \\
\text { gipsatury wewnętrznej. Strącona } \\
\text { również latarnia z krzyżem na } \\
\text { dzwonnicy }\end{array}$ & Uszkodzony \\
\hline K. 64 & Zawalów & Hrubieszowski & $\begin{array}{l}\text { Kościół zrujnowany zewnątrz } \\
\text { i wewnątrz obdarty, odrapany, } \\
\text { przez okupanta niemieckiego } \\
\text { miał być zamieniony na łaźnię }\end{array}$ & Uszkodzony \\
\hline K. 71 & Dzwola & Janowski lubelski & Brak szyb, uszkodzenia dachu & Uszkodzony \\
\hline К. 74 & Modliborzyce & Janowski lubelski & Częściowo zniszczony & Uszkodzony \\
\hline K. 78 & Wierzchowiska & Janowski lubelski & $\begin{array}{l}\text { W kościele i budynku } \\
\text { parafialnym stłuczonych } 150 \\
\text { szyb i } 3000 \text { dachówek }\end{array}$ & Uszkodzony \\
\hline K. 85 & Stężyca Łęczyńska & Krasnostawski & $\begin{array}{l}\text { Był uszkodzony w trzech } \\
\text { miejscach od pocisków, } \\
\text { podziurawiony dach i ściany } \\
\text { od kul karabinowych oraz } \\
\text { ogrodzenie cmentarza }\end{array}$ & Uszkodzony \\
\hline K. 80 & Żulin, par Żulin-Borowica & Krasnostawski & $\begin{array}{l}\text { Dach blaszany podziurawiony } \\
\text { od pocisków i bomby, która } \\
\text { zwaliła kopułę i przez to pół } \\
\text { dachu uszkodziła. Leje się, } \\
\text { rynny poniszczone całkowicie }\end{array}$ & Uszkodzony \\
\hline K. 101 & Lubartów & Lubartowski & $\begin{array}{l}\text { Zbite okna w liczbie } 39 \text { i jeden } \\
\text { witraż, zrabowany dzwon wagi } \\
1700 \mathrm{~kg} \text {, zniszczone ogrodzenie }\end{array}$ & Uszkodzony \\
\hline K. 99 & $\begin{array}{l}\text { Lubartów Klasztor Braci } \\
\text { Mniejszych Kapucynów }\end{array}$ & Lubartowski & Dach uszkodzony & Uszkodzony \\
\hline K. 102 & Michów & Lubartowski & $\begin{array}{l}\text { Wskutek nalotu niemieckiego } \\
\text { w } 1944 \text { r. został podziurawiony } \\
\text { na zewnątrz }\end{array}$ & Uszkodzony \\
\hline K. 103 & Niemce & Lubartowski & $\begin{array}{l}\text { Uszkodzony, zerwany dach, } \\
\text { wybite okna, popękany } \\
\text { i uszkodzony na zewnątrz }\end{array}$ & Uszkodzony \\
\hline K. 104 & Ostrówek & Lubartowski & $\begin{array}{l}\text { Dach blaszany podziurawiony } \\
\text { od pocisków i bomby }\end{array}$ & Uszkodzony \\
\hline k. 106 & Serniki & Lubartowski & $\begin{array}{l}\text { Naruszone okna od strony } \\
\text { południowej od wybuchu } \\
\text { w składzie amunicji w pobliskim } \\
\text { lesie w } 1944 \text { r. }\end{array}$ & Uszkodzony \\
\hline K. 17 & Abramowice & Lubelski & $\begin{array}{l}\text { Zniszczone okna, } \\
\text { podziurawiony dach }\end{array}$ & Uszkodzony \\
\hline K. 112 & Opole & Opolski & $\begin{array}{l}\text { Rozbite witraże i okna, dach } \\
\text { uszkodzony }\end{array}$ & Uszkodzony \\
\hline
\end{tabular}




\begin{tabular}{|c|c|c|c|c|}
\hline 1 & 2 & 3 & 4 & 5 \\
\hline K. 113 & Piotrawin & Opolski & $\begin{array}{l}\text { Kościół rozbity bez dachu, } \\
\text { zniszczony w } 40 \% \text {, dzwonnica } \\
\text { spalona i rozbite mury, kaplica } \\
\text { rozbita, zniszczona w } 50 \%\end{array}$ & Uszkodzony \\
\hline K. 114 & Prawno & Opolski & $\begin{array}{l}\text { Uszkodzenie ścian, dachu przez } \\
\text { działania wojenne, obrabowanie } \\
\text { aparatów kościelnych, } \\
\text { zniszczenie organów }\end{array}$ & Uszkodzony \\
\hline K. 118 & Zagłoba & Opolski & Uszkodzone wszystkie okna & Uszkodzony \\
\hline $\begin{array}{l}\text { K. } 138 \text { verte, } \\
135\end{array}$ & $\begin{array}{l}\text { Józefów Biłgorajski } \\
\text { (Ordynacki) }\end{array}$ & Tarnogrodzki & $\begin{array}{l}\text { Uszkodzony na zewnątrz przez } \\
\text { kule armatnie }\end{array}$ & Uszkodzony \\
\hline K. 139 & Księżpol & Tarnogrodzki & $\begin{array}{l}\text { Przyniszczony wewnątrz przez } \\
\text { Ukraińców, zdemolowany } \\
\text { w czasie okupacji niemieckiej }\end{array}$ & Uszkodzony \\
\hline K. 41 & Potok Górny & Tarnogrodzki & $\begin{array}{l}\text { Brak blachy na szczytach dachu } \\
30 \text { arkuszy, organy rozstrojone } \\
\text { i brak tynku na ogrodzeniu }\end{array}$ & Uszkodzony \\
\hline K. 142 & Łosiniec & Tomaszowski & Zniszczony, zbite okna & Uszkodzony \\
\hline K. 143 & Podhorce & Tomaszowski & $\begin{array}{l}\text { Dach na kościele spalony, trzy } \\
\text { dziur w murze }\end{array}$ & Uszkodzony \\
\hline K. 145 & Tarnawatka & Tomaszowski & $\begin{array}{l}\text { Okna zniszczone, mury oraz } \\
\text { wnętrze częściowo uszkodzone }\end{array}$ & Uszkodzony \\
\hline K. 153 & Turobin & Turobiński & $\begin{array}{l}\text { Okna wybite, parkan zburzony, } \\
\text { posadzka zapadła się. Od } \\
\text { września } 1942 \text { do kwietnia } \\
1943 \text { r. w kościele Niemcy } \\
\text { urządzili magazyn na zboże, to } \\
\text { ujemnie wpłynęło na posadzkę, } \\
\text { która bardziej niż przedtem } \\
\text { zaczęła się zapadać, szczególnie } \\
\text { w górnej nawie oraz w kaplicy } \\
\text { św. Anny }\end{array}$ & Uszkodzony \\
\hline K. 154 & Wysokie & Turobiński & Uszkodzony dach i okna & Uszkodzony \\
\hline K. 155 & Żółkiewka & Turobiński & $\begin{array}{l}\text { Uszkodzenie tynków } \\
\text { zewnętrznych, częściowo przez } \\
\text { działania wojenne }\end{array}$ & Uszkodzony \\
\hline K. 156 & $\begin{array}{l}\text { Dołhobyczów, par } \\
\text { Dołhobyczów-Oszczów }\end{array}$ & Tyszowiecki & $\begin{array}{l}\text { Spalony lub zdewastowany } \\
\text { przez Ukraińców }\end{array}$ & Uszkodzony \\
\hline K. 157 & Mircze & Tyszowiecki & Zniszczone wnętrze i dach & Uszkodzony \\
\hline K. 156 & Nowosiółki & Tyszowiecki & $\begin{array}{l}\text { Spalony lub zdewastowany } \\
\text { przez Ukraińców }\end{array}$ & Uszkodzony \\
\hline K. 156 & Wiszniów & Tyszowiecki & $\begin{array}{l}\text { Spalony lub zdewastowany } \\
\text { przez Ukraińców }\end{array}$ & Uszkodzony \\
\hline K. 156 & $\begin{array}{l}\text { Zubowice - drewniany } \\
\text { pounicki zabytek }\end{array}$ & Tyszowiecki & $\begin{array}{l}\text { Spalony lub zdewastowany } \\
\text { przez Ukraińców }\end{array}$ & Uszkodzony \\
\hline
\end{tabular}




\begin{tabular}{|c|c|c|c|c|}
\hline 1 & 2 & 3 & 4 & 5 \\
\hline K. 156 & Żulice, par Rzeplin-Żulice & Tyszowiecki & $\begin{array}{l}\text { Spalony lub zdewastowany } \\
\text { przez Ukraińców }\end{array}$ & Uszkodzony \\
\hline K. 161 verte & $\begin{array}{l}\text { Cześniki filia parafii } \\
\text { Horyszów Polski }\end{array}$ & Zamojski & $\begin{array}{l}\text { Pozostał bez urządzenia } \\
\text { wewnętrznego, ogrodzenie } \\
\text { zniszczone, budynki mieszkalne } \\
\text { i ekonomiczne zniszczone }\end{array}$ & Uszkodzony \\
\hline K. 161 & Horyszów Polski & Zamojski & $\begin{array}{l}\text { Uszkodzone ogrodzenie } \\
\text { i wywiezione całe urządzenie } \\
\text { wewnętrzne przez wysiedlonych } \\
\text { Ukraińców }\end{array}$ & Uszkodzony \\
\hline K. 162 & Krasnobród & Zamojski & Częściowe uszkodzenia & Uszkodzony \\
\hline K. $164-165$ & Łabunie & Zamojski & $\begin{array}{l}\text { Dach w wielu miejscach } \\
\text { dziurawy, fronton kościoła- } \\
\text { fasada w środku zrujnowana, } \\
\text { tynk z cegłami odpada w wielu } \\
\text { miejscach, kaplica obok kościoła } \\
\text { murowana w stanie dobrym, do } \\
\text { kaplicy przylega sala parafialna } \\
\text { też w stanie dobrym, dzwonnica } \\
\text { na cmentarzu kościelnym też } \\
\text { wymaga remontu, plebania } \\
\text { drewniana, stara ale jeszcze } \\
\text { w stanie dobrym, organistówka } \\
\text { mocno zrujnowana wymaga } \\
\text { remontu, wikariat nowy jeszcze } \\
\text { nie zupełnie wykończony, } \\
\text { budynki ekonomiczne na } \\
\text { probostwie stare ale jeszcze } \\
\text { zdatne do użytku }\end{array}$ & Uszkodzony \\
\hline K. 168 & Stary Zamość & Zamojski & $\begin{array}{l}\text { Dach } 400 \text { dziur, wyrwy w murze } \\
\text { zewnętrznym, w } 4 \text { oknach brak } \\
\text { szyb }\end{array}$ & Uszkodzony \\
\hline K. 169 & Suchowola Zamojska & Zamojski & $\begin{array}{l}\text { Brak sklepienia w wieży nad } \\
\text { wejściem i nad bocznym } \\
\text { wejściem oraz takich samych } \\
\text { dwóch sklepień na I piętrze. } \\
\text { Brak urządzeń wewnętrznych: } \\
\text { ołtarzy, ambon, ławek, } \\
\text { konfesjonałów dostosowanych } \\
\text { do stylu kościoła, uszkodzony } \\
\text { we wrześniu } 1939 \text { r., otwór } \\
\text { w sklepieniu od pocisku } \\
\text { armatniego, kilka szczerb we } \\
\text { frontonie wieży, podziurawiony } \\
\text { dach, wybite szyby w oknach, } \\
\text { wyrzucone w } 1943 \text { r. ołtarze, } \\
\text { organy i wszystko co w kościele } \\
\text { było, bo z kościoła urządzono } \\
\text { w czasie wysiedleń bunkier } \\
\text { obronny, w którym była } \\
\text { kuchnia w zakrystii, prycze do } \\
\text { spania w nawach bocznych, } \\
\text { a w piwnicy pod zakrystią ustęp; } \\
\text { zrabowano część aparatów } \\
\text { i bielizny kościelnej, zabrano } \\
\text { dwa dzwony, cztery chorągwie } \\
\text { i feretron }\end{array}$ & Uszkodzony \\
\hline
\end{tabular}




\begin{tabular}{|c|c|c|c|c|}
\hline $\mathbf{1}$ & 2 & 3 & 4 & 5 \\
\hline K. 67 & $\begin{array}{l}\text { Łążek Zaklikowski, kaplica } \\
\text { parafii Borów }\end{array}$ & Janowski lubelski & $\begin{array}{l}\text { Kościół miał wszystkie okna } \\
\text { pobite, dach podziurawiony, } \\
\text { dwie kruchty pozbawione } \\
\text { zupełnie dachu, jednego ołtarza, } \\
\text { dzwonnica doszczętnie spalona, } \\
\text { kaplica w Łążku wewnątrz } \\
\text { zdewastowana, wszystkie okna } \\
\text { pobite }\end{array}$ & $\begin{array}{l}\text { Uszkodzony } \\
\text { kościół i kaplica }\end{array}$ \\
\hline K. 73 & Janów Lubelski & Janowski lubelski & $\begin{array}{l}\text { Cały dach zrujnowany, } \\
\text { sklepienie przebite w dwóch } \\
\text { miejscach, zburzony boczny } \\
\text { filar, wszystkie szyby wvbite, } \\
\text { trzy okna wyrwane, budynki } \\
\text { ekonomiczne spalone. Kościół } \\
\text { rektoralny p.w. Wszystkich } \\
\text { Świętych we wsi Biała, } \\
\text { zbudowany w latach } 1922-29 \\
\text { podczas działań wojennych roku } \\
1939 \text { został spalony z całym } \\
\text { urządzeniem łącznie z plebanią } \\
\text { i budynkami ekonomicznymi }\end{array}$ & $\begin{array}{l}\text { Uszkodzony, } \\
\text { uszkodzony } \\
\text { również kościół } \\
\text { rektoralny } \\
\text { w Białej }\end{array}$ \\
\hline K. 53 & $\begin{array}{l}\text { Horyszów Ruski filia parafii } \\
\text { Gdeszyn }\end{array}$ & Hrubieszowski & $\begin{array}{l}\text { W czasie okupacji zamieniony } \\
\text { na łaźnię }\end{array}$ & $\begin{array}{l}\text { Uszkodzony, } \\
\text { zamieniony na } \\
\text { łaźnię }\end{array}$ \\
\hline K. 171 & Zamość & Zamojski & $\begin{array}{l}\text { Kościół dwukrotnie był zajęty } \\
\text { przez Niemców na magazyny } \\
\text { wojskowe, dlatego został } \\
\text { wewnątrz mocno zabrudzony. } \\
\text { Parkan w całości zrabowany. } \\
\text { Kościół popękał, dach został } \\
\text { uszkodzony, siatki przy oknach } \\
\text { porozrywane }\end{array}$ & $\begin{array}{l}\text { Uszkodzony, } \\
\text { zamieniony } \\
\text { na magazyn } \\
\text { zbożowy }\end{array}$ \\
\hline K. 54 & Grabowiec & Hrubieszowski & $\begin{array}{l}\text { Zniszczony wewnątrz } \\
\text { i na zewnątrz, zamieniony na } \\
\text { magazyn zbożowy }\end{array}$ & $\begin{array}{l}\text { Uszkodzony, } \\
\text { zamieniony } \\
\text { na magazyn } \\
\text { zbożowy }\end{array}$ \\
\hline K. 30 & Matczyn & Bełżycki & $\begin{array}{l}\text { kościół drewniany zmurszały, } \\
\text { murowany, stracił część } \\
\text { materiałów }\end{array}$ & $\begin{array}{l}\text { utracone } \\
\text { materiały na } \\
\text { budowę nowego } \\
\text { kościoła }\end{array}$ \\
\hline K. 79 & Zdziłowice & Janowski lubelski & W budowie od $1939 \mathrm{r}$. & $\begin{array}{l}\text { W trakcie } \\
\text { budowy }\end{array}$ \\
\hline K. 91 & Brzeźnica Książęca & Lubartowski & W budowie od $1935 \mathrm{r}$. & $\begin{array}{l}\text { W trakcie } \\
\text { budowy }\end{array}$ \\
\hline K. 107 & Starościn & Lubartowski & W trakcie kończenia budowy & $\begin{array}{l}\text { W trakcie } \\
\text { budowy }\end{array}$ \\
\hline K. 124 & Klementowice & Puławski & $\begin{array}{l}\text { Kontynuacja budowy kościoła } \\
\text { od } 1914 \text { r. }\end{array}$ & $\begin{array}{l}\text { W trakcie } \\
\text { budowy }\end{array}$ \\
\hline K. 60 & Tuczępy & Hrubieszowski & $\begin{array}{l}\text { Brak było } 10 \text { okien, ścian } \\
\text { wewnętrznych, } 4 \text { drzwi, sufitu, } \\
\text { podłogi }\end{array}$ & $\begin{array}{l}\text { W trakcie } \\
\text { budowy }\end{array}$ \\
\hline K. 58 & Szpikołosy & Hrubieszowski & $\begin{array}{l}\text { Zamieniony na cerkiew } \\
\text { prawosławną. W latach 1919- } \\
1945 \text { nabożeństwa odbywały się } \\
\text { w domu prywatnym z powodu } \\
\text { zajęcia tego kościoła na cerkiew } \\
\text { prawosławną. }\end{array}$ & $\begin{array}{l}\text { Zamieniony } \\
\text { na cerkiew } \\
\text { prawosławną }\end{array}$ \\
\hline
\end{tabular}




\begin{tabular}{|l|l|l|l|l|}
\hline \multicolumn{1}{|c|}{$\mathbf{1}$} & \multicolumn{1}{|c|}{$\mathbf{2}$} & \multicolumn{1}{c|}{$\mathbf{3}$} & \multicolumn{1}{c|}{$\mathbf{4}$} \\
\hline K. 87 & Żdżanne & Krasnostawski & $\begin{array}{l}\text { Kościół posiadał urządzenia } \\
\text { wewnętrzne, które po } \\
\text { zabraniu kościoła na cerkiew } \\
\text { prawosławną 23 XI 1940 r. } \\
\text { zostały zniszczone zupełnie }\end{array}$ & $\begin{array}{l}\text { Zamieniony } \\
\text { na cerkiew } \\
\text { prawosławną }\end{array}$ \\
\hline $\begin{array}{l}\text { K. 138-138 } \\
\text { verte, 133 }\end{array}$ & Biszcza & Tarnogrodzki & $\begin{array}{l}\text { Wojną nie uszkodzony, w czasie } \\
\text { okupacji niemieckiej był } \\
\text { przerobiony na prawosławną } \\
\text { cerkiew, więc wewnątrz } \\
\text { zdemolowany }\end{array}$ & $\begin{array}{l}\text { Zamieniony } \\
\text { na cerkiew } \\
\text { prawosławną }\end{array}$ \\
\hline K. 139, 136 & Luchów Górny & Tarnogrodzki & $\begin{array}{l}\text { Uszkodzony na zewnątrz, } \\
\text { podziurawiony dach blaszany od } \\
\text { południowej strony, wewnątrz } \\
\text { był zdemolowany, przerobiony } \\
\text { na cerkiew prawosławną }\end{array}$ & $\begin{array}{l}\text { Zamieniony } \\
\text { na cerkiew } \\
\text { prawosławną }\end{array}$ \\
\hline K. 140 & Zamch & Tarnogrodzki & $\begin{array}{l}\text { Zamieniony na cerkiew } \\
\text { prawosławną }\end{array}$ & $\begin{array}{l}\text { Zamieniony } \\
\text { na cerkiew } \\
\text { prawosławną }\end{array}$ \\
\hline
\end{tabular}

Źródło: AAL, Wydział Artystyczno-Budowlany, Ogólne zestawienie kosztów, sygn. Dz. IV 3033.

Tabela 2. Wykaz kościołów, które według sprawozdań administratorów nie ucierpiały w czasie wojny

\begin{tabular}{|l|l|l|l|}
\hline $\begin{array}{l}\text { Nr karty } \\
\text { jednostki } \\
\text { archiwalnej }\end{array}$ & $\begin{array}{l}\text { Parafia, filia, kaplica, } \\
\text { klasztor }\end{array}$ & Dekanat w 1948 r. & Stan w 1944 r. \\
\hline \multicolumn{1}{|c|}{$\mathbf{1}$} & \multicolumn{1}{|c|}{$\mathbf{3}$} & $\mathbf{4}$ \\
\hline K. 22 & Babin & Bełżycki & Nie ucierpiał od działań wojennych \\
\hline K. 23 & Bełżyce & Bełżycki & Nie ucierpiał od działań wojennych \\
\hline K. 26 & Chodel & Bełżycki & Nie ucierpiał od działań wojennych \\
\hline K. 28 & Kiełczewice & Bełżycki & Nie ucierpiał od działań wojennych \\
\hline K.29 & Krężnica Jara & Bełżycki & Nie ucierpiał od działań wojennych \\
\hline K.32 & Ratoszyn & Bełżycki & Nie ucierpiał od działań wojennych \\
\hline K. 37 & Goraj & Biłgorajski & Nie ucierpiał od działań wojennych \\
\hline K. 39 & Lipiny & Biłgorajski & Nie ucierpiał od działań wojennych \\
\hline K. $43-44$ & Radzięcin & Biłgorajski & Nie ucierpiał od działań wojennych \\
\hline K.45 & Sól & Biłgorajski & Nie ucierpiał od działań wojennych \\
\hline K. 69 & Batorz & Janowski lubelski & Nie ucierpiał od działań wojennych \\
\hline K. 66 & Blinów & Janowski lubelski & Nie ucierpiał od działań wojennych \\
\hline K. 68 & Branew & Janowski lubelski & Nie ucierpiał od działań wojennych \\
\hline K. 70 & Chrzanów & Janowski lubelski & Nie ucierpiał od działań wojennych \\
\hline K. 77 & Potok Wielki & Janowski lubelski & Nie ucierpiał od działań wojennych \\
\hline K. 80 & Borowica, parafia Żulin- & Krasnostawski & Nie ucierpiał od działań wojennych \\
\hline K. 89 & Abrowica & Lubartowski & Nie ucierpiał od działań wojennych \\
\hline K.90 & Brzeźnica Bychawska & Lubartowski & Nie ucierpiał od działań wojennych \\
\hline
\end{tabular}




\begin{tabular}{|c|c|c|c|}
\hline 1 & 2 & 3 & 4 \\
\hline K. 92 & Czemierniki & Lubartowski & Nie ucierpiał od działań wojennych \\
\hline K. 93 & Firlej & Lubartowski & Nie ucierpiał od działań wojennych \\
\hline K. 97 & $\begin{array}{l}\text { Jadwinów kaplica parafii } \\
\text { św. Anny Matki NMP } \\
\text { w Lubartowie }\end{array}$ & Lubartowski & Nie ucierpiał od działań wojennych \\
\hline K. 94 & Kamionka & Lubartowski & Nie ucierpiał od działań wojennych \\
\hline K. 96 & Leszkowice & Lubartowski & Nie ucierpiał od działań wojennych \\
\hline K. 105 & Rudno & Lubartowski & Nie ucierpiał od działań wojennych \\
\hline K. 19 & Dys & Lubelski & Nie ucierpiał od działań wojennych \\
\hline K. 20 & Konopnica & Lubelski & Nie ucierpiał od działań wojennych \\
\hline K. 13 & $\begin{array}{l}\text { Lublin Kalinowszczyzna } \\
\text { św. Agnieszka }\end{array}$ & Lubelski & Nie ucierpiał od działań wojennych \\
\hline K. 16 & $\begin{array}{l}\text { Lublin, św. Michała } \\
\text { Archanioła }\end{array}$ & Lubelski & Nie ucierpiał od działań wojennych \\
\hline K. 21 & Motycz & Lubelski & Nie ucierpiał od działań wojennych \\
\hline K. 109 & Karczmiska & Opolski & Nie ucierpiał od działań wojennych \\
\hline K. 110 & Kluczkowice & Opolski & Nie ucierpiał od działań wojennych \\
\hline K. 46 & Nałęczów - Bochotnica & Puławski & Nie ucierpiał od działań wojennych \\
\hline K.138 & Aleksandrów & Tarnogrodzki & Nie ucierpiał od działań wojennych \\
\hline K. 138 verte & Górecko & Tarnogrodzki & Nie ucierpiał od działań wojennych \\
\hline K. 139 & Łukowa & Tarnogrodzki & Nie ucierpiał od działań wojennych \\
\hline K. 137 & Tarnogród & Tarnogrodzki & Nie ucierpiał od działań wojennych \\
\hline K. 140 & Tarnogród Św. Roch & Tarnogrodzki & Nie ucierpiał od działań wojennych \\
\hline K. 141 & $\begin{array}{l}\text { Jarczów, parafia Jarczów- } \\
\text { Chodywańce }\end{array}$ & Tomaszowski & Nie ucierpiał od działań wojennych \\
\hline K. 146 & Tomaszów Lubelski & Tomaszowski & Nie ucierpiał od działań wojennych \\
\hline K. 149 & Chłaniów & Turobiński & Nie ucierpiał od działań wojennych \\
\hline K. 150 & Czernięcin & Turobiński & Nie ucierpiał od działań wojennych \\
\hline K. 151 & Gilów & Turobiński & Nie ucierpiał od działań wojennych \\
\hline K. 84 & Stara Wieś & Turobiński & Nie ucierpiał od działań wojennych \\
\hline
\end{tabular}

Źródło: AAL, Wydział Artystyczno-Budowlany, Ogólne zestawienie kosztów, sygn. Dz. IV 3033.

Informacja, że kościół nie ucierpiał, nie jest równoznaczna z tym, że teren parafii nie był objęty działaniami wojennymi. Cudowna moc ocaliła kościół w Tomaszowie Lubelskim, gdyż jak zaobserwował oficer niemieckiego lotnictwa, którego celem bombardowania była kościelna wieża, ilekroć kierował na nią celownik, jakaś niezrozumiała siła przeszkadzała mu wypełnić zadanie i bomby nie osiągały celu ${ }^{34}$.

\footnotetext{
${ }^{34}$ Tomaszów Lubelski, s. 448.
} 
W związku ze skutkami wojennej pożogi trud odbudowy zniszczonych i uszkodzonych w czasie wojny kościołów diecezji lubelskiej podjął pełniący od marca 1946 roku funkcję ordynariusza lubelskiego bp Stefan Wyszyński (19461948), powołując w sierpniu 1948 roku Biskupi Komitet Odbudowy Kościołów Diecezji Lubelskiej ${ }^{35}$. Zauważał on, że poniszczone na skutek działań wojennych i czasu świątynie, które przedstawiają także bogaty materiał kulturalny, wymagają opieki, która byłaby prowadzona w sposób planowy i zorganizowany.

W liście do duchowieństwa i wiernych napisanym na Uroczystość Wniebowzięcia NMP 1948 roku apelował o zaangażowanie wszystkich wiernych w pomoc parafiom najdotkliwiej doświadczonych wojną. Przytoczone przez nas w całości słowa pasterskiego listu bpa ordynariusza lubelskiego Stefana Wyszyńskiego, są świadectwem ogromnej troski, nie tylko o dotknięte wojną kościoły, lecz także o losy ludzi, ich spalone domostwa i warunki bytowe.

$\mathrm{Na}$ ostatnim, sierpniowym, zjeździe księży dziekanów powołany został do życia Biskupi Komitet Odbudowy zniszczonych Kościołów Diecezji Lubelskiej.

Racją bytu tego Komitetu jest fakt, że południowe i zachodnie dekanaty diecezji naszej ucierpiały więcej, w czasie wojny, niż centralne. Zubożała wskutek wysiedleń $\mathrm{i}$ walk frontowych ludność nie jest zdolna sama sobie poradzić. Całe połacie ziemi lubelskiej są w odbudowie; wznoszone są chaty i zagrody. Najlepsi nawet katolicy tych terenów, pomimo swej ofiarności, sami jednak podołać nie mogą, by odbudować swe świątynie. Raz po raz zwracają się do nas o pomoc, o słowa zachęty, czy o błogosławieństwo. Nieraz drobna pomoc nasza podnosi ducha Braci naszych i krzepi ich siły.

W tej ciężkiej pracy i walce o odbudowanie ziem zniszczonych, Bracia nasi nie mogą pozostać osamotnieni. Musimy stanąć przy nich, i pomocą, radą, życzliwością, ofiarą dodawać ducha.

Tworzymy jedną rodzinę katolicką; wspólna jest nasza droga do Boga, wspólny wódz-Jezus Chrystus, wspólna Matka-Kościół święty, jedna wiara, jeden chrzest i jedno kapłaństwo. W imię tej wspólnoty jedne członki Kościoła mają miłować drugie i wspólnie dźwigać swoje brzemiona.

I wojenne doświadczenia mamy udźwignąć społem, mamy wydobyć się z pod gruzów, stanąć przy ołtarzach ofiary i dźwignąć upadłe wieżyce nadziei. Jak pomagaliśmy sobie w czasie wojny modlitwą i ofiarą, tak i dziś pomożemy sobie zachętą, sercem i groszem w odbudowaniu cennych pamiątek naszej wiary i pobożności, tych zabytkowych niekiedy świątyń, świadków naszej wysokiej kultury narodowej i religijnej.

Biskupi Komitet Odbudowy, zanim będzie mógł rozwinąć szerszą działalność już dziś odwołuje się do katolików, by nie szczędzili grosza na świątynie katolickie w ziemi hrubieszowskiej, tyszowieckiej, tomaszowskiej, puławskiej, czy opolskiej.

Postanowiliśmy przeprowadzić $w$ najbliższych miesiącach trzy kwesty w świątyniach naszych, w czasie sumy: niedzieli dnia 14 listopada, w uroczystość Trzech Króli, w Niedzielę Palmową. Do ofiar zebranych

${ }^{35}$ AAL, Wydział Artystyczno-Budowlany, Kwesty na budowę i odbudowę kościołów 19481950, sygn. Dz. IV 3037, [jednostka poświęcona Biskupiemu Komitetowi Odbudowy Kościołów Diecezji Lubelskiej]. 
w kościołach zasobniejszych parafii dołącza się inne środki, które umożliwią nam wczesną wiosną przystąpić do dzieła odbudowy.

Odezwę naszą zwracamy do zasobniejszych parafii, liczących od trzech tysięcy wiernych. Nie chcemy jednak zamykać drogi do zasługi mniej liczebnym parafiom, zwłaszcza jeżeli same nie są zajęte odbudową swoich świątyń.

Fundusze tak zebrane Komitet przydzieli kościołom najbardziej zagrożonym. Umożliwi to prace zasadnicze, odbudowę zwalonych ścian, pokrycie dachami, nabycie najbardziej koniecznych urządzeń i sprzętów liturgicznych.

Do Duchowieństwa diecezji naszej zwracam się z braterską prośbą, aby Współbraciom naszym - kapłanom, borykającym się w chwalebnym trudzie na swych zniszczonych placówkach, podali życzliwą dłoń, troskliwi o chwałę Bożą, której szukamy. Wiemy jak nierówne są warunki pracy naszej. Są parafie zasobne, urządzone wzorowo, zaopatrzone we wszystko; obok nich mamy ubożuchne kościółki, jak stajenka betlejemska. Sami zadbajmy o to, by tę nierówność złagodzić i wiernych wzywajmy do rozszerzania serc swoich. Niech uczą się miłować bezinteresownie i czynnie cały Kościół Boży, a nie tylko swoją parafię. Niech w tym czynie ofiarnym odmieni się ich rozumienie Kościoła, jako Matki o powszechnym sercu. Niech wyzwolą się z partykularyzmu, który niekiedy jest przyczyną niepokoju i niezgody. Apelujcie do cnoty wielkoduszności, do ich braterstwa w Chrystusie ! Odbudujemy Braciom naszym, doświadczonym przez wojnę, świątynie podźwigniemy ich ducha, dodamy otuchy w walce z męką dnia powszedniego.

Dobry Bóg spojrzy radosnym sercem na naszą ofiarę i jej pobłogosławi. A świat ujrzy piękny przykład dla siebie: „Patrzcie, jak oni się miłują”.

$\mathrm{Na}$ niwę słów zachęty niech spłynie nasze błogosławieństwo pasterskie i niech trwa nad Wami.

W kolejnej odezwie do wiernych diecezji lubelskiej biskup S. Wyszyński nawoływał do podjęcia wspólnego wysiłku odbudowy zniszczonych świątyń, jednocześnie uświadamiając ludowi skalę zniszczeń:

Czy pojedziemy nad Wisłę, gdzie toczyły się długie boje frontu, czy udamy się za Huczwę i Tanew, czy nad Bug, widzimy dotąd tyle kościołów zniszczonych. Dawniej tu modlił się lud, tu słuchał słowa Bożego, krzepił się Ciałem Chrystusa. Dziś świątynie wymarłe, ołtarze zburzone, wnętrza porosłe chwastem, zasypane gruzami $^{36}$.

Ponadto apelował do rządców kościołów, aby w pierwszej kolejności przystąpili do planowania i podejmowania prac najpilniejszych, uwrażliwiając ich jednocześnie na trudne warunki bytowe samych parafian:

Mając na uwadze ciężkie warunki gospodarcze ludności trzeba podejmować w parafii prace rozważnie i wykonywać je oszczędnie. Nie należy dopuszczać parafii do zadłużenia ${ }^{37}$.

${ }^{36}$ „Wiadomości Diecezjalne Lubelskie” (dalej WDL), 25 (1948) nr 10, s. 357-360 (Akta Biskupa Lubelskiego: Biskupi Komitet Odbudowy Kościołów Diecezji Lubelskiej; Odezwa Biskupa Lubelskiego w sprawie odbudowy zburzonych kościołów rzymsko-katolickich w diecezji lubelskiej).

${ }^{37} \mathrm{WDL}, 25$ (1948) nr $1 \mathrm{~s} .5-7$ (W sprawie prac budowlanych i remontów przy świątyniach). 
Skład Komitetu Odbudowy w świetle jego Statutu tworzyli: biskup ordynariusz diecezji lubelskiej jako przewodniczący Komitetu; w dalszej kolejności wikariusz generalny biskupa lubelskiego; skarbnik, powoływany przez zjazd księży dziekanów; sekretarz Komitetu, którym był dziekan dekanatu lubelskiego, a także dziekani następujących dekanatów: hrubieszowskiego, kraśnickiego, opolskiego, puławskiego, tomaszowskiego i tyszowieckiego. Komisja rewizyjna składająca się z trzech osób była wybierana przez Zjazd Księży Dziekanów.

Fundusze Komitetu Odbudowy stanowiły tace kościelne zbierane w świątyniach parafii, liczących powyżej trzech tysięcy wiernych, dobrowolne ofiary i zapisy, a także dotacje uzyskane od właściwych władz oraz kwesty publiczne na terenie diecezji ${ }^{38}$.

Jak wynika z naszych zestawień, większość świątyń posiadała zniszczenia zewnętrzne w postaci uszkodzonego dachu, ścian, okien, drzwi, parkanu, kilka kościołów zostało doszczętnie spalonych, a te które zamieniano na cerkwie prawosławne, magazyny wojskowe czy łaźnie, zostały pozbawione wewnętrznego wyposażenia.

Remonty tych najdotkliwiej zniszczonych kościołów wymagały dużych nakładów finansowych, którym miejscowa ludność ponosząca koszty odbudowy własnych gospodarstw, nie mogła sama sprostać. Bez wsparcia zewnętrznego, jak pisał jeden z administratorów parafii, odbudowa świątyń jest niemożliwa, gdyż:

Ludność jest biedna, siedzi we wsiach spalonych, w dołach ziemnych lub prowizorycznych mieszkaniach na prędce zrobionych ze słomy i płotów. Wsie w 90\% spalone. Kosztorys odbudowy drewnianych kościołów w Rzeplinie, Honiatyczach i Oszczowie w przybliżeniu oprócz materiału drzewnego wynosiłby $3 \mathrm{mln}$ zł. Kosztorys remontu kosciołów w Zubowicach, Wiszniowie, Nowosiółkach i Żulicach wynosiłby $2 \mathrm{mln} \mathrm{z}^{39}$.

Również proboszcz parafii Nabróż prosząc o wsparcie finansowe, przyznał, że: „Parafia w 75\% spalona. Ludność bardzo biedna. Kompletny brak funduszów. Bez pomocy finansowej z zewnątrz stanie praca odbudowy a świątyni grozi ruina" ${ }^{40}$. O pomoc w odbudowie kościołów zwracali się również proboszcz parafii Prawno i parafii Wilków podkreślając, że: ,parafia biedna bo zniszczona wojną i częstymi powodziami, ludzie dają chętnie, ale dużo naraz nie mogą (...), dlatego robót szybko ukończyć się nie da"41.

W niektórych przypadkach poważnych uszkodzeń doznawało tak wnętrze kościoła, jak i jego zewnętrzne ściany, a także budynki parafialne, jak np. w parafii Łabunie

gdzie kościół w czasie działań wojennych 1939 roku mało ucierpiał stosunkowo, poza dziurami od kul w dachu większych uszkodzeń nie było. Wewnątrz jednak został mocno zbrudzony bo przetrzymywano w nim we wrześniu 1939 roku jeńców wojennych, a od 1942 do 1944 roku w czasie wysiedlenia służył

${ }^{38}$ AAL, Wydział Artystyczno-Budowlany, Kwesty na budowę i odbudowę, sygn. Dz. IV 3037, k. 9-10.

${ }^{39}$ AAL, Wydział Artystyczno-Budowlany, Ogólne zestawienie kosztów..., sygn. Dz. IV 3033, k. 156.

${ }^{40}$ Tamże, k. 158.

${ }^{41}$ Tamże, k. 114, 116. 
Niemcom jako magazyn na zboże. W roku 1945 w czasie niszczenia bomb lotniczych przez Sowietów mury kościelne i sklepienie w wielu miejscach popękało. Fronton kościoła - fasada grozi niebezpieczeństwem, cegły z tynkiem odpadają, wieżyczka kościelna wymaga przebudowy, drewno zgniłe i dach dziurawy na niej. Dach na kościele przecieka, należy go zmienić, bo już rdza blachę zniszczyła. Kaplica służyła Niemcom w czasie wojny jako stajnia na konie, a sowietom na mieszkania, zniszczona bardzo, niezdatna do użytku. Sala parafialna zniszczona wewnątrz zupełnie przez wybuchy granatów we wrześniu 1939 roku Dzwonnica w stanie złym, dach dziurawy a drzewo zgniłe. Krzyż nawet nie może się prosto trzymać. Plebania w ciągu wojny służyła jako mieszkanie dla ks. Proboszcza, ale prócz niego mieszkało kilka rodzin chłopskich-spaleńców. Mieszkali też w niej Niemcy, a potem sowieci. Zniszczona bardzo i zewnątrz i wewnątrz. Organistówkę Niemcy w czasie wysiedleń zamienili na oborę i stajnię, a potem sowieci na kuchnię dla wojska. Zniszczona bardzo. Niezdatna do zamieszkania. Budynki ekonomiczne na probostwie zostały wszystkie spalone w roku 1939 przez działania wojenne ${ }^{42}$.

Zrujnowane budowle sakralne wpisywały się w ogólny obraz powojennej pożogi w województwie lubelskim. Rozmiar strat materialnych zarejestrowało i oszacowało Ministerstwo Odbudowy w Warszawie, czego wyniki zwierają poniższe zestawienia.

Tabela 3. Zestawienie szkód wojennych w miastach województwa lubelskiego

\begin{tabular}{|l|l|l|l|}
\hline Miasto & $\begin{array}{l}\text { Liczba } \\
\text { budynków }\end{array}$ & $\begin{array}{l}\text { Kubatura } \\
\mathbf{w ~ m}^{\mathbf{3}}\end{array}$ & $\begin{array}{l}\text { Wartość } \\
\text { zniszczeń w zl }\end{array}$ \\
\hline Lublin, Biskupice, Bychawa, Piaski i Puchaczów & 1283 & 317800 & 6638900 \\
\hline Krasnystaw & 115 & 51300 & 754200 \\
\hline Chełm, Pawłów, Świerże & 101 & 21700 & 347000 \\
\hline Hrubieszów & 41 & 17000 & 610000 \\
\hline Łęczna, pow. Lubartów & 15 & 25500 & 445100 \\
\hline Frampol, Goraj, Tarnogród, Krzeszów, pow. Biłgoraj & 1063 & 20000 & 600000 \\
\hline Biała Podlaska i Leśna Podlaska & 144 & 103200 & 4392000 \\
\hline Janów Lubelski, Kraśnik, Annopol, Zaklików & 471 & 1311900 & 22725000 \\
\hline Włodawa, Parczew, Wisznice, Ostrów & 1044 & 55700 & 665000 \\
\hline Tomaszów Lubelski, Jarczów, Łaszczów, Komarów & 852 & 51050 & 1012000 \\
\hline Siedlce & 1047 & 142900 & 3042200 \\
\hline Radzyń i Międzyrzecz & 256 & 40200 & 1387000 \\
\hline Zamość, Szczebrzeszyn, Krasnobród & 81 & 4065 & 118630 \\
\hline Ogółem & 6513 & 2162315 & 42737030 \\
\hline
\end{tabular}

W aktach drukiem wytluszczonym zapisano miasta powiatowe i powiaty.

Źródło: Archiwum Akt Nowych w Warszawie [dalej: AAN], Ministerstwo Odbudowy, Szkody wojenne na terenie województwa lubelskiego. Wykazy ogólne i zestawienie według miejscowości, sygn. $314 / 204$

${ }^{42}$ Tamże, k. 164-165. 
Tabela 4. Zestawienie szkód wojennych wsi województwa lubelskiego

\begin{tabular}{|l|l|l|l|}
\hline Lp. & Powiaty & Liczba zagród & Wartość zniszczeń w zl \\
\hline 1. & Hrubieszowski & 7177 & 12200000 \\
\hline 2. & Siedlecki & $\mathbf{1 5 0 0}$ & 7800000 \\
\hline 3. & Bialski & $\mathbf{9 0 8}$ & 5100000 \\
\hline 4. & Lukowski & $\mathbf{7 4 0}$ & 4218000 \\
\hline 5. & Janowski Lubelski & 2079 & 3775100 \\
\hline 6. & Włodawski & 1215 & 2673000 \\
\hline 7. & Tomaszowski & 1099 & 2307900 \\
\hline 8. & Puławski & 907 & 1890700 \\
\hline 9. & Chełmski & 924 & 1654000 \\
\hline 10. & Biłgorajski & 676 & 1285000 \\
\hline 11. & Krasnostawski & 620 & 1104400 \\
\hline 12. & Radzyński & 150 & 435000 \\
\hline 13. & Zamojski & 1722 & 354000 \\
\hline 14. & Lubelski & 142 & 313700 \\
\hline 15. & Lubartowski & 179 & 275900 \\
\hline & Ogółem & 20038 & 45386700 \\
\hline
\end{tabular}

Drukiem wytłuszczonym zapisano liczbę zagród, które zsumowano łącznie z budynkami użyteczności publicznej.

Źródło: AAN, Ministerstwo Odbudowy, Szkody wojenne na terenie województwa lubelskiego. Wykazy ogólne i zestawienie wedtug miejscowości, sygn. 314/204.

Pomimo stosowanych przez Niemców represji, dużą rolę w walce o przetrwanie poprzez pomoc materialnąi i wsparcie duchowe odegrał Kościół rzymskokatolicki ${ }^{43}$, przyjmując pod dach plebanii wiernych, których wojna pozbawiła podstawowych warunków bytowych, a przede wszystkim siły do dalszego życia. Skala zniszczeń kościołów i budynków parafialnych na obszarze diecezji lubelskiej była bardzo poważna i dotkliwa, a trud odbudowy nawet tych najbardziej zniszczonych świątyń spoczął na wiernych. Ważną kwestią, pominiętą w tekście, a zasługującą na odrębną publikację, pozostaje odbudowa zniszczonej działaniami wojennymi katedry lubelskiej i jej architektonicznych koncepcji, które - jak dowodzi tego materiał archiwalny zgromadzony w lubelskim Archiwum Archidiecezjalnym wzbudzały wiele emocji.

${ }^{43}$ Markiewicz, Dzieje Bitgoraja, s. 230. 


\section{BIBLIOGRAFIA}

\section{Źródła}

\section{Archiwum Akt Nowych w Warszawie}

Ministerstwo Odbudowy, Szkody wojenne na terenie województwa lubelskiego. Wykazy ogólne i zestawienie według miejscowości, sygn. 314/204.

\section{Archiwum Archidiecezjalne Lubelskie}

Wydział Artystyczno-Budowlany, Ogólne zestawienie kosztów na roboty remontowe i odbudowę zburzonych przez działania wojenne lub budowę nowych 1947-, sygn. Dz. IV 3033.

Wydział Artystyczno-Budowlany, Kwesty na budowę i odbudowę kościołów 1948-1950, sygn. Dz. IV 3037.

Wydział Artystyczno-Budowlany, Korespondencja dotycząca spraw budownictwa kościelnego 1951-1976, sygn. Dz. IV 3025.

\section{Prasa}

„Wiadomości Diecezjalne Lubelskie”, 25 (1948) nr 1 s. 5-7 (W sprawie prac budowlanych i remontów przy światyniach).

„Wiadomości Diecezjalne Lubelskie”, 25 (1948), nr 10 s. 357-360 (Akta Biskupa Lubelskiego: Biskupi Komitet Odbudowy Kościołów Diecezji Lubelskiej; Odezwa Biskupa Lubelskiego $w$ sprawie odbudowy zburzonych kościołów rzymsko katolickich $w$ diecezji lubelskiej).f

\section{Opracowania}

Diecezja Lubelska. Informator historyczny i administracyjny, oprac. M.T. Zahajkiewicz, Lublin 1985.

Gałecka Marzena, Zniszczenia i straty $w$ zabytkach nieruchomych $w$ granicach obecnego województwa lubelskiego poniesione w wyniku II wojnie światowej, „Wiadomości Konserwatorskie Województwa Lubelskiego", 8 (2006) s. 188-207.

Gawarecki Henryk, Kronika. Prace konserwatorskie. Województwo Lubelskie (19451946), „Ochrona Zabytków”, 5 (1952) nr 4 (19) s. 271-277.

Gawarecki Henryk, Kronika. Prace konserwatorskie. Województwo Lubelskie (19531957), „Ochrona Zabytków”, 11 (1958) nr 1-2 s. 119-129.

Kulik Marian, Zamojszczyzna pamięta i oskarża..., Lublin 2009.

Markiewicz Jerzy, Szczygieł Ryszard, Śladkowski Wiesław, Dzieje Biłgoraja, Lublin 1985.

Mazurkiewicz Witold Piotr, Kurów lubelski w XX stuleciu, Lublin 2002.

Niedźwiedź Ewa, Niedźwiedź Józef, Siudak Józef, Dzieje miejscowości gminy Miączyn. Powiat zamojski, t. 3, Miączyn-Zamość 2005.

Ogiński Janusz, Wilków n. Wisła. Wieś, parafia, kościót p.w. śś. Floriana i Urszuli. (szkic do monografii), (mps w Wojewódzkiej Bibliotece Publicznej im. H. Łopacińskiego w Lublinie, Dział Bibliografii Lubelszczyzny i Wiedzy o Regionie), [b.m.w.] 1996.

Polska i Puławy ,na głównym szlaku duchowych dziejów”, red. T. Giergiel, Puławy 2017. Spis kościołów i duchowieństwa diecezji lubelskiej 1948, Lublin 1948.

Tokarczyk Roman, Turobin. Dzieje miejscowości, Lublin 2002.

Tomaszów Lubelski. Monografia miasta, red. R. Szczygieł, Lublin-Tomaszów Lubelski 2011. 
Walewander Edward, Diecezja lubelska, w: Życie religijne $w$ Polsce pod okupacja hitlerowska 1939-1945, red. Z. Zieliński, Warszawa 1982.

Wójcik Robert, Kościoły Garbowa, Garbów 1997.

Zabytki Architektury i Budownictwa w Polsce. Województwo Lubelskie, oprac. H. Gawarecki, B. Wolff-Łozińska, J. Łoziński, t. 8, z. 8, Warszawa 1973.

Zieliński Władysław, 600 lat Oszczowa, Lublin 2009.

\title{
DAMAGE TO SACRAL BUILDINGS IN THE DIOCESE OF LUBLIN AFTER WORLD WAR II
}

\begin{abstract}
Summary
The post-war picture of damage to parish churches of the Lublin diocese presented in the paper was based on the material gathered primarily in the Archdiocesan Archive of Lublin. The sources for the tabular study are derived from the forms containing information on damage to churches. These forms were sent by the administrators of the parishes to the Curia in Lublin in 1948. Their analysis reveals that a great number of churches in the Lublin diocese were affected by war. The deaneries which suffered the most serious damage were as follows: Zamość, Hrubieszów, Tarnogród, Tomaszów (south-east and east ones) as well as Puławy and Opole (west deaneries). Due to the shortage of material, it was impossible to present the whole damage done to all the churches in the Lublin diocese. The fragmentary presentation of the losses the parish churches in the Lublin diocese sustained during World War II shows that in most cases the external elements of the churches were damaged: roofs, towers, window panes, walls, fences; moreover, several churches were converted into granaries or Orthodox churches, while others were burnt down. The commitment of the faithful engaged in rebuilding the churches, as well as the Committee for the Reconstruction of the Churches in the Lublin Diocese set up by the Ordinary Bishop of Lublin, Stefan Wyszyński, played the major role in the restoration of the ruined churches.
\end{abstract}

Key words: a church; a parish; a diocese; World War II; rebuilding; war losses 